\title{
PRIMJENA KRUTOG STAJSKOG GNOJA NA TRAVNJACIMA
}

\author{
Marina Vranić, K. Bošnjak, Anja Novak, Ines Lisjak, Ana Trubelja, \\ Matea Županović, G. Kiš
}

\begin{abstract}
Sažetak
Travnjaci predstavljaju sirovinsku osnovu stočarske proizvodnje. Gnojidba travnjaka je agrotehnički zahvat koji se provodi u cilju proizvodnje krme visokog prinosa i visoke hranidbene vrijednosti za hranidbu životinja. Svaka farma proizvodi stajski gnoj kao posljedicu držanja životinja, a travnjak je idealno mjesto za primjenu, a time i zbrinjavanje proizvedenog stajskog gnoja.

Cilj ovog rada bio je prikazati: (i) osnovne aspekte primjene gnojiva na travnjacima s naglaskom na primjenu krutog stajskog gnoja (KSG), (ii) preporučene količine, vrijeme primjene i frekvenciju primjene KSG na travnjacima, (iii) utjecaj primjene KSG na travnjacima na prinos i hranidbenu vrijednost krme i (v) neke od negativnih posljedica primjene KSG na travnjacima.

KSG ima visoki potencijal u gnojidbi travnjaka. Njegovim zbrinjavanjem na travnjacima dolazi do recikliranja hranjiva i povećanja organske tvari u tlu, povećanja vodnog i vodozračnog kapaciteta tla te promicanja održivosti poljoprivrednih ekosustava. KSG se preporuča koristiti u svim sustavima poljoprivredne proizvodnje, osobito u ekološkom uzgoju. Radi visoke varijabilnosti kemijskog sastava KSG te utjecaja mikroklime, tla i vode na usvajanje hranjivih tvari od strane biljaka, neophodno je provoditi vlastita istraživanja na određenim mikroklimatskim lokacijama u cilju utvrđivanja optimalne količine, frekvencije i vremena primjene na prinos i hranidbenu vrijednost krme.
\end{abstract}

Ključne riječi: travnjak, kruti stajski gnoj, gnojidba

\section{Uvod}

Najvažnija uloga travnjaka je proizvodnja voluminozne krme za hranidbu domaćih životinja sa složenim želucima, odnosno, preživača. Potencijal travnjaka, obzirom na prinos i hranidbenu vrijednost voluminozne krme, može se ostvariti primjenom različitih agrotehničkih zahvata od kojih je jedan i gnojidba (Štybnarova i sur, 2014.). Gnojidbom se tlu nadoknađuju hranjiva iznesena prinosom kako bi se izbjeglo iscrpljivanje tla i popravio proizvodni potencijal (Štybnarova i sur, 2014.).

Gnojidba utječe na botanički sastav tratine, rast biljaka, sposobnost produkcije sjemena, rast i razvoj biljnih organa pod zemljom, broj i vrste mikroorganizama u tlu, vodni kapacitet tla te kompeticiju između biljnih vrsta (Rabotnov, 1977.). Gnojidba povećava kvalitetu krme, otpornost tratine na bolesti i klimatske stresove (Rabotnov, 1977.), utječe na sve sastavnice plodnosti tla i formiranje stabilne strukture tla što za posljedicu ima bolje vodozračne odnose i viši hranidbeni kapacitet tla (Kisić, 2014.).

Prof. dr. sc. Marina Vranić, izv. prof. dr. sc. Krešimir Bošnjak, corresponding autor: e-mail: kbosnjak@agr.hr, Sveučilište u Zagrebu Agronomski fakultet, Zavod za specijalnu proizvodnju bilja,

Anja Novak, Ines Lisjak, Ana Trubelja, Matea Županović, studentice na Sveučilištu u Zagrebu Agronomski fakultet,

izv. prof. dr. sc. Goran Kiš, Sveučilište u Zagrebu Agronomski fakultet, Zavod za hranidbu životinja, Svetošimunska cesta 25, 10000 Zagreb, Hrvatska 
Prije primjene gnojiva, treba provesti kontrolu plodnosti tla (otprilike svakih pet godina) radi utvrđivanja trenutnog stanja plodnosti (Mesić i sur., 2008.) i potrebe na hranjivima (Kisić, 2014.). Plodnost tla se može definirati kao sposobnost osiguravanja biljci hranjivih tvari, vode, zraka i topline koji su joj potrebni za pravilan rast i razvoj (Butorac, 1999.) u cilju stvaranja optimalnog prinosa po jedinici površine (Kisić, 2014.).

Gnojiva su prema Kisiću (2014.) bilo koji materijal, organski ili anorganski koji se u tlo unosi gnojidbom. Prema Bašiću i Hercegu (2010.) gnojidba tla je zahvat ili skup zahvata kojima se tlo obogaćuje hranjivima.

\section{Podjela gnojiva}

Osnovna podjela gnojiva je na gnojiva organskog i mineralnog (tvornička gnojiva) porijekla. Organska gnojiva u svom sastavu imaju dosta organske tvari i male količine mikro i makro hranjiva, a mineralna gnojiva imaju veću koncentraciju osnovnih hranjiva i ne sadrže organske spojeve (Gašpar, 1996.).

\section{Mineralna gnojiva}

Mineralna gnojiva su soli, dobivene kemijskom obradom ili sintezom prirodnih sirovina, koje u svojem sastavu imaju biogene elemente u većoj koncentraciji od bilo kojeg organskog gnojiva (Bašić i Herceg, 2010.). Sva biljna hranjiva se u mineralnim gnojivima nalaze u pristupačnim oblicima za biljku (Gašpar, 1996.). Naziv mineralna gnojiva se prema Bašiću i Hercegu (2010.) odnosi na teoriju o mineralnoj ishrani bilja, a ne na sastav, jer uključuju i ureu koja je organski spoj.

Mineralna gnojiva se prema sastavu dijele na pojedinačna i složena. Pojedinačna mineralna gnojiva su ona koja sadrže samo jedno hranjivo i prema tome se dijele na makrognojiva (ako sadrže makroelement) i mikrognojiva (ako sadrže mikroelement). Složena mineralna gnojiva u svom sastavu sadrže više hranjiva i ovisno o njihovom broju se dijele na dvojna, trojna ili cjelovita gnojiva. Nadalje, obzirom na broj zastupljenog gnojiva, složena gnojiva se prema sastavu ili načinu proizvodnje dijele na: kompleksna i miješana. Kompleksna se proizvode kemijskom reakcijom uz otapanje ili granulaciju s navedenim udjelom najmanje dva primarna hraniva. Miješana gnojiva proizvode se suhim miješanjem nekoliko gnojiva bez kemijske reakcije (Bašić i Herceg, 2010.).

Mineralna gnojiva su ključna za opskrbu tala hranjivima radi postizanja visokih i stabilnih prinosa biljne mase (Bašić i Herceg, 2010.) iako postoje dvojbe oko njihova korištenja jer su izvor onečišćenja tala i podzemnih voda teškim metalima (Bašić i Herceg, 2010.) i mogu negativno utjecati na bioraznolikost (Tallowin i sur., 1994.).

Bioraznolikost biljnih vrsta na vlažnim livadama se može značajno smanjiti i kod primjene samo $25 \mathrm{~kg} \mathrm{~N} \mathrm{ha}^{-1}$ godišnje (Tallowin i sur., 1994.). Primjena mineralnih dušičnih gnojiva dovodi do dominacije trava na vlažnim livadama i smanjuje brojnost biljnih vrsta, pa vrstama bogate livade pretvara u vrstama siromašne livade (Tallowin i sur., 1994., Tallowin i Smith, 1994.).

Procijenjeno je da za vraćanje vegetacije livada u prvobitno stanje bioraznolikosti, nakon primjene $25 \mathrm{~kg} \mathrm{~N}$ ha $^{-1}$ godišnje treba 2 godine, nakon primjene $50 \mathrm{~kg} \mathrm{ha}^{-1} \mathrm{~N}$ treba 4 godine, a nakon primjene $100 \mathrm{~kg} \mathrm{~N} \mathrm{ha}^{-1}$ godišnje treba 7 godina (Tallowin i sur., 1994.). 


\section{Organska gnojiva}

Organska gnojiva su prirodni materijali biljnog ili životinjskog porijekla koji uključuju stajski gnoj, zelenu gnojidbu, biljne ostatke, kućanski otpad i kompost (Kisić, 2014.). Po kemijskom sastavu i po koncentraciji hranjivih tvari, organska gnojiva su siromašnija od mineralnih gnojiva, ali su radi velikog sadržaja organske tvari i mikrohranjiva visoke vrijednosti i stanovitih prednosti u odnosu na mineralna gnojiva.

Organska gnojiva otpuštaju hranjiva kroz duži period i tako dugoročno poboljšavaju kemijske, fizikalne i mikrobiološke značajke tla. Hranjiva iz organskih gnojiva, u kojima se nalaze u organski vezanom nepristupačnom obliku za biljku (Kisić, 2014.), biljka može usvojiti tek nakon mikrobiološkog procesa mineralizacije organske tvari (Bašić i Herceg, 2010; Kisić, 2014.).

U organska gnojiva ubrajamo kruti stajski gnoj (KSG), gnojovku ili polutekuće stajsko gnojivo i gnojnicu ili tekući stajski gnoj (Kisić, 2014.).

\section{Kruti stajski gnoj}

Nakon prelaska čovjeka na sjedilački način života počelo je aktivno primjenjivanje KSG-a u poljoprivrednoj proizvodnji (Archer, 1986.). Prije proizvodnje umjetnih gnojiva, upotreba KSG je bila osnovno sredstvo povećanja prinosa i kvalitete travnjaka i strukture tla (Duffey, 1974.).

KSG se dobiva stajskim držanjem domaćih životinja uz primjenu stelje (Bašić i Herceg, 2010.). Prema Pravilniku o dobroj poljoprivrednoj praksi (MPRRR, 2008) KSG je smjesa stelje, krutih i tekućih životinjskih izlučevina različitog stupnja biološke razgrađenosti, stabilnosti i zrelosti.

Primjenom KSG tlu se dodaju hranjive tvari i mijenja njihova ravnoteža, a posljedično i njihovo usvajanje od strane biljaka. KSG povećava sadržaj organske tvari u tlu (povećava sadržaj proteinskog sumpora u tlu, količinu elemenata u tragovima, ima puferni utjecaj na $\mathrm{pH}$ tla i povećava mikrobnu populaciju u tlu), povećava vodni i vodozračni kapacitet tla, utječe i brojnost vrsta beskralježnjaka na tlu i ispod površine tla (Carson i Pickett, 1990; Zheng i sur., 2010.; Wang, 2014.; FAO, 2017.).

Kruti stajski gnoj sadrži sve potrebne tvari za rast biljaka, poput dušika, kalija, magnezija i kalcija, pa se njegovom primjenom može promijeniti botanički sastav tratine i povećati biomasa travnjaka (Carson i Pickett, 1990.).

Radi gore navedenih prednosti korištenja organskih gnojiva u usporedbi s mineralnim gnojivima te promicanja održivosti poljoprivrednih ekosustava (Zheng i sur., 2010.), organska gnojiva se preporuča koristiti u sustavima poljoprivredne proizvodnje (Ulen, 1993.), posebno u ekološkom uzgoju (Lamkin, 1990.). Visoki je potencijal primjene stajskog gnoja u gnojidbi travnjaka, ali nedovoljno iskorišten resurs u Republici Hrvatskoj (Knežević i sur, 2007.). Svaka farma proizvodi stajski gnoj kao posljedicu držanja životinja. Travnjak je idealno mjesto za primjenu, a time i zbrinjavanje stajskog gnoja čime dolazi do recikliranja hranjiva i minimalnog nedostatka minerala u tlu (Knežević i sur, 2007.).

\section{Kemijski sastav KSG-a}

KSG je složeno heterogeno organsko gnojivo promjenjivog kemijskog sastava i kad je dobiveno od iste životinje držane na istoj stelji. Kemijski sastav KSG-a ovisi o vrsti, spolu i uzrastu domaće životinje, količini i kvaliteti krme korištene za hranidbu, načinu držanja stoke, vrsti i 
količini primijenjene stelje, klimatskim prilikama područja te načinu skladištenja i manipulacije (Bašić i Herceg, 2010.).

Prosječan kemijski sastav gnojiva različitih vrsta domaćih životinja je prikazan u tablici 1 (Ball i sur, 2002.).

Tablica 1. Prosječan kemijski sastav gnoja različitih vrsta domaćih životinja $\left(\mathrm{kg} \mathrm{t}^{-1}\right.$ svježeg gnoja)

Table 1 The average chemical composition of manure originated from different domestic animals $\left(\mathrm{kg} \mathrm{t}^{-1}\right.$ fresh manure)

\begin{tabular}{cccccc}
\hline \multirow{2}{*}{$\begin{array}{c}\text { Hranjivo/ } \\
\text { Nutrient }\end{array}$} & \multicolumn{5}{c}{ Vrsta životinje / Animal species } \\
\cline { 2 - 6 } & $\begin{array}{c}\text { Mliječna } \\
\text { goveda / } \\
\text { Dairy cattle }\end{array}$ & $\begin{array}{c}\text { Mesna } \\
\text { goveda / } \\
\text { Beef cattle }\end{array}$ & $\begin{array}{c}\text { Perad / } \\
\text { Poultry }\end{array}$ & $\begin{array}{c}\text { Svinje / } \\
\text { Swine }\end{array}$ & $\begin{array}{c}\text { Ovce / } \\
\text { Sheep }\end{array}$ \\
\hline $\mathrm{N}$ & 4,54 & 6,356 & 11,35 & 4,54 & 12,71 \\
\hline $\mathrm{P}$ & 2,27 & 1,82 & 5,0 & 1,27 & 1,91 \\
\hline $\mathrm{K}$ & 3,63 & 4,1 & 4,54 & 3,45 & 9,1 \\
\hline $\mathrm{S}$ & 0,68 & 0,77 & 4,45 & 1,23 & 0,82 \\
\hline $\mathrm{Ca}$ & 2,3 & 1,1 & 16,34 & 5,18 & 5,31 \\
\hline $\mathrm{Mg}$ & 0,91 & 0,91 & 2,72 & 0,73 & 1,68 \\
\hline Vlaga/moisture \% & 85 & 85 & 72 & 82 & 77 \\
\hline
\end{tabular}

$\mathrm{N}$, dušik; P, fosfor; $\mathrm{K}$, kalij; S, sumpor; $\mathrm{Ca}$, kalcij; $\mathrm{Mg}$, magnezij.

$\mathrm{N}$, nitrogen; $\mathrm{P}$, phosphorus; $\mathrm{K}$, potassium; $\mathrm{S}$, sulfur; $\mathrm{Ca}$, calcium; $\mathrm{Mg}$, magnesium.

KSG je bogat makrohranjivima (dušikom, fosforom, kalijem, kalcijem i magnezijem), a sadrži i sva mikrohranjiva. Dobro pripremljen, zreo stajski gnoj, sadrži oko $35 \%$ trajnog humusa. Stajski gnoj dobiven od različitih životinja u prosjeku sadrži 0,45-0,50\% N; 0,20 $0,25 \% \mathrm{P}_{2} \mathrm{O}_{5} ; 0,50-0,60 \% \mathrm{~K}_{2} \mathrm{O}$ i $20 \%$ organske tvari (Butorac, 1999.). Hranjive tvari iz gnojiva se mogu reciklirati na farmi, ali upotreba je često niska radi promjenjivog i nepoznatog sastava te poteškoća s odgovarajućom primjenom i vremenom primjene, što rezultira gubicima hranjivih tvari ispiranjem i otjecanjem (Lampkin 1990.).

\section{Gubitci hranjivih tvari iz stajskog gnoja}

Prilikom manipulacije, skladištenja i primjene stajskog gnoja neminovni su gubitci hranjiva. Prozračivanje i izloženost KSG atmosferilijama dovodi do većih gubitaka $\mathrm{N}$ isparavanjem amonijaka. Uobičajeni gubici $\mathrm{N}$, isparavanjem amonijaka iz stajskog gnoja, iznose $20-30 \%$, minimalni $10-16 \%$, a maksimalni $30-51 \%$ u slučaju neadekvatnog skladištenja na otvorenom gnojištu (Lampkin 1990.). Gubici N isparavanjem iz stajskog gnoja se kreću 10-50\% (najčešće $20 \%$ ), a mogući su i gubici P oko 7\% te K oko 35\% (Powlson i sur., 1994.).

Gubitci N ovise i o vremenskim uvjetima te načinu primjene. Kod površinske upotrebe KSG na travnjacima velika količina $\mathrm{N}$ se izgubi u atmosferi, pa ostaje neiskorišten od strane biljke i zagađuje okolišs. 


\section{Količina, frekvencija i vrijeme primjene KSG na travnjacima}

Količina, frekvencija i vrijeme primjene KSG je najviše ovisno o fitocenološkim, klimatskim i pedološkim uvjetima određenog područja. Radi mogućih visokih varijacija sastava KSG, u usporedbi s mineralnim gnojivima, teže je optimizirati gnojidbu travnjaka KSG obzirom na vrijeme, frekvenciju i primjenjenu količinu (Thomas i Xiying, 2017.; Kim i sur., 2014.).

\section{Vrijeme primjene KSG}

Prema rezultatima ranijih istraživanja, razlikuju se preporuke vremena primjene KSG na travnjacima.

Prema nekim autorima, najpovoljnije vrijeme za primjenu KSG na travnjacima je razdoblje aktivnog porasta biljke kada su joj hranjiva najpotrebnija, odnosno u rano proljeće prije početka vegetacije kada je iskorištenje hranjiva efikasnije u odnosu na jesensku ili zimsku gnojidbu (Wilson i sur, 2009.; Lampkin, 1990.; Smith, 1991.) radi manjih gubitaka N nastalih ispiranjem dušika tijekom zime (Smith i Unwin,1983.). Međutim, utvrđeno je da se isparavanjem amonijaka tijekom ožujka i travnja gube velike količine dušika iz KSG (Lampkin, 1990.).

U proljetnom periodu je KSG najefikasnije primijeniti u kasno zimskoj ili rano proljetnoj gnojidbi travnjaka (Smith, 1991.), krajem veljače ili u ožujku (Lampkin, 1990.). S druge strane, upotreba gnojiva od siječnja do ožujka koči rani rast trava radi potiskivanja i paleži, ali učinci su neznatni kad se usklade primijenjene količine gnojiva i nutritivne potrebe usjeva (Smith, 1991.). Ako se primjenjuje u proljeće, KSG treba primijeniti dovoljno rano da se spriječi kontaminacija prvog otkosa krme.

Utvrđene su prednosti rano jesenske gnojidbe travnjaka KSG čime se osiguravaju hranjiva biljkama prije zimskog mirovanja vegetacije (Peel, 1938.). Ako se travnjak gnoji od rujna do prosinca KSG baziranim na slami, smanjuje se rizik ispiranja dušika (Chambers, 1994.) kada je optimalno vrijeme primjene KSG na travnjacima u studenom (Arnold, 1976.).

Reakcije travnjaka na KSG su najmanje predvidive kod ljetne gnojidbe kada usjevi, ovisno o vremenu, uzimaju gotovo ništa ili skoro svu dostupnu količinu dušika iz gnojiva (Smith, 1980.).

Prema nekim navodima (Butorac, 1999.) vrijeme primjene KSG je najviše ovisno o sastavu tla i klimi.

\section{Količina i frekvencija primjene KSG}

Osim odluke o vremenu primjene gnojiva, važno je utvrditi racionalnu količinu gnojiva koja odgovara potrebama biljaka, stanju usjeva, plodnosti tla, a paralelno tome mora se paziti na klimatske uvjete i mogući prinos (Kisić, 2014.; Mesić i sur., 2008.).

U teža tla treba unijeti veću količinu hranjivih tvari da bi im se povećala plodnost (Simpson i Jefferson, 1996.). Kod zasnivanja travnjaka najbolje je u tlo zaorati 20 - 35 t KSG ha-1 (Simpson i Jefferson, 1996.). Peel (1938.) preporuča gnojidbu travnjaka s 25 - 37 t KSG ha-1 svake treće ili četvrte godine, a u međuvremenu savjetuje upotrebu mineralnih gnojiva radi održavanja visokog prinosa biljne mase. U cilju očuvanja bioraznolikosti travnjaka i poluprirodnih livada, količina primijenjenog KSG ne bi trebala prijeći $20 \mathrm{t}$ ha ${ }^{-1}$ svakih tri do pet godina, kao jednokratna gnojidba (Crofts i Jefferson, 1994.). Niže količine od 20 t KSG ha-1 poželjne su na područjima gdje se želi očuvati, ali i povećati bioraznolikost (Crofts i Jefferson, 1994.). 
Prema rezultatima istraživanja primjene KSG na travnjacima u Velikoj Britaniji, 30-40 t KSG ha ${ }^{-1}$ potiskuje biljne vrsta i dovodi do djelomičnog propadanja usjeva, pa se preporuča optimalna količina od 20-30 t KSG ha-1 godišnje (Simpson i Jefferson, 1996.).

\section{Način primjene $\mathrm{KSG}$}

Gnojivo treba primijeniti neposredno po dopremi na travnjak. Distribucija KSG po travnjaku tijekom vrućeg vremena dovodi do velikog gubitka hranjivih tvari, osobito $\mathrm{N}$ isparavanjem.

Uobičajen način primjene KSG-a je upotrebom traktorskih prikolica za distribuciju gnoja s mehanizmom za razbacivanje. Mehanizam se zasniva na rotirajućim krilcima, postavljenim na kraju lanca u pravilnim razmacima, koja bacaju i razbacuju gnojivo postrance do $3 \mathrm{~m}$. Fizička svojstva gnojiva utječu na uspješnost i ujednačenost distribucije (Malgeryd, 1994.).

Kako bi raspršivanje bilo što efikasnije raspršivači trebaju biti pouzdani s mogućnošću podešavanja količine gnojiva, laki za održavanje, izrađeni od materijala otpornih na koroziju koji ravnomjerno razbacuju gnojivo.

\section{Učinci primjene KSG na travnjacima}

Reakcije tratine na primjenu KSG ovise o vremenu i vrsti gnojiva, učešću u tratini biljaka koje brže koriste gnojivo, sustavima korištenja travnjaka i stadiju razvoja tratine u trenutku aplikacije gnojiva.

\section{Učinci primjene KSG na biljni sastav travnjaka}

Utjecaj gnojidbe KSG na biljni pokrov ovisi o početnoj plodnosti tla, načinu gospodarenja travnjakom, početnom biljnom sastavu, načinu proizvodnje i skladištenja KSG, distribuciji, te količini, frekvenciji i vremenu primjene. Sukladno tome, mijenja se efekt primjene KSG na biljne vrste, od održavanja postojeće bioraznolikosti preko neznatnih sezonskih promjena do potpunih promjena biljnog sastava travnjaka (Lawes i Gilbert, 1859.; Van den Bergh, 1991.).

Primijenjena agrotehnologija uzgoja dovodi do promjena flornog sastava tratine i u slučaju sjetve jedne biljne vrste (Jones, 1933.).

Općenito, primjena KSG povećava udio trava u tratini radi njihovog bržeg rasta i veće visine kod intenzivnije gnojidbe na štetu dvosupnica i nižih biljnih vrsta, te mijenja omjere postojećih vrsta trava (Lawes i Gilbert, 1859.; Van den Bergh, 1991.).

Stapledon i Hanley (1927.), navode da primjena $15 \mathrm{t} \mathrm{KSG} \mathrm{ha}^{-1}$ svake druge godine povećava udio poželjnih trava, a smanjuje udio nepoželjnih trava (niske hranidbene vrijednosti) u tratini. S druge strane, Dodd i sur. (1994.) navode da je gnojidba s 35 t KSG ha ${ }^{-1}$ svake četvrte godine premala za održavanje prirodne konzervacijske vrijednosti poluprirodnih livada.

Međutim, pojedine biljne vrste i njihovi varijeteti se razlikuju u kompeticijskoj sposobnosti, pa visokoprinosne trave mogu biti slabije kompetitivosti u odnosu na niskoprinosne vrste, osobito u neoptimalnim uvjetima uzgoja (Van der Berg, 1991.).

\section{Utjecaj gnojidbe KSG na prinos krme}

Gnojidba brdsko planinskih poluprirodnih travnjaka KSG može povećati prinos suhe tvari (ST) travnjaka za 0,5-2,5 $\mathrm{t} \mathrm{ha}^{-1}$ i hranjivost krme, osobito u sušnim godinama (Julianna i sur., 2013.). 
Prinos ST travnjaka se može povećati sa oko $2,5 \mathrm{t} \mathrm{ha}^{-1}$ bez gnojidbe na oko $6.0 \mathrm{t} \mathrm{ha}^{-1}$ sa primjenom 60 t KSG ha' ${ }^{-1}$ godišnje tijekom 11 godina (Dijk i sur., 1990.).

Osim povećanja prinosa ST, gnojidba travnjaka povećava ukupnu hranidbenu vrijednost krme (Malgeryd, 1994.; McCartney i sur., 2004.), koja predstavlja koncentraciju hranjivih tvari po jedinici ST i količinu krme koju životinja može konzumirati (Vranić i sur., 2004., 2005.; Knežević i sur., 2007.). Gnojidbom se povećava sadržaj sirovog proteina (SP) krme (McCartney i sur., 2004.), udio lista, brzina probave stanične stjenke, konzumacija ST, opskrbljenost životinje amino-kiselinama (Van Soest i sur., 1991.), a time ukupna hranidbena vrijednost krme u hranidbi životinja (Vranić i sur., 2004., 2005.; Knežević i sur., 2007.).

Gnojidba usjeva sirka s 10 t $\mathrm{KSG}^{-1} \mathrm{~h}^{-1}$ rezultirala je većim sadržajem sirovih proteina (SP) prvog otkosa za 9,15\%, a drugog otkosa za 8,57\% u usporedi s kontrolnim tretmanom (bez primjene KSG) (Gill i Vear, 1968.). Gnojidba travnjaka s 30 t KSG ha ${ }^{-1}$ rezultirala je većim prinosom ST travnjaka i većim sadržajem SP u usporedbi s primjenom 0 i $15 \mathrm{t} \mathrm{KSG} \mathrm{ha}^{-1}$ (Patel i sur., 2008.).

\section{Negativni utjecaj primjene KSG na travnjacima}

KSG može uzrokovati neugodne mirise okoline (radi otpuštanja amonijaka i dušikovog oksida u atmosferu). Iz KSG može doći do otjecanja i ispiranja hranjiva, odnosno, do onečišćenja okoliša i gubitka hranjivih tvari, a može uzrokovati „gušenje“ biljaka te širenje korovskih vrsta.

Ispiranje hranjiva i onečišćenje okoliša te gubitak hranjivih tvari nakon primjene KSG na travnjacima ovise o nagibu površine, tipu tla i vremenskih uvjetima nakon gnojidbe te kemijskom sastavu i fizikalnim karakteristikama primijenjenog KSG (Lampkin, 1990.). Na prirodno dreniranim travnjačkim tlima na gubitak dušika ispiranjem utječe vrsta gnojiva, vrijeme primjene i količina padalina tijekom zime (Chambers, 1994.).

Nakon primjene KSG na travnjacima može doći dio tzv. „gušenja“ biljaka radi možebitne prevelike količine primijenjenog KSG i njegove neravnomjerne distribucije što ovisi i o količini, sastavu, zrelosti, vremenu primjene i vremenskim uvjetima, pa treba koristiti dobro usitnjeni, zreli stajski gnoj i ravnomjerno ga raspršiti po travnjaku.

Primjena KSG pogoduje širenju pojedinih biljnih vrsta. Utvrđeno je da se u $6 \mathrm{t} \mathrm{KSG}$ nalazi oko 50000 sjemenki (Korsmo, 1938.). Sjemenke korova u KSG mogu potjecati od stelje, krme korištene u hranidbi, vozila i drugog otpada na farmi (Gill i Vear, 1968.). Sjemenke nekih biljnih vrsta prolaskom kroz probavni trakt životinje gube na klijavosti ovisno o vremenu provedenom u probavnom traktu (Müller-Schneider, 1986., Simao Neto i Jones, 1987.). Širenje korovskih vrsta primjenom KSG se može smanjiti ako KSG fermentira i zrije na višoj temperaturi $\left(65,6^{\circ} \mathrm{C}\right)$ jer se time smanjuje klijavost korovskih sjemenki (Simao Neto i Jones, 1987.).

Osim širenja nepoželjnih biljnih vrsta, primjena KSG može prouzročiti i botaničke promjene travnjaka, potaknuti veću kompeticiju među vrstama za dostupna hranjiva (Berendse i Elberse, 1990.) te potiskivati poželjne biljne vrste (Berendse i Elberse, 1990.). 


\section{Zaključak}

Radi visoke varijabilnosti kemijskog sastava KSG te utjecaja mikroklime, tla i voda na usvajanje hranjivih tvari od strane biljaka, neophodno je provoditi vlastita istraživanja na određenim mikroklimatskim lokacijama u cilju utvrđivanja optimalne količine, frekvencije i vremena primjene na prinos i hranidbenu vrijednost krme. KSG ima visoki potencijal u gnojidbi travnjaka. Njegovim zbrinjavanjem na travnjacima dolazi do recikliranja hranjiva i povećanja organske tvari u tlu, povećanja vodnog i vodozračnog kapaciteta tla te promicanja održivosti poljoprivrednih ekosustava. KSG se preporuča koristiti u svim sustavima poljoprivredne proizvodnje, a posebno u ekološkom uzgoju.

\section{LITERATURA}

1. Archer J. (1986.): Grassland manuring, past and present. In: J.C.Cooper and W.F. Raymond, eds. Grassland Manuring. Occasional Symposium No. 20. British Grassland Society, 5-14.

2. Arlond P.W., Hunter, F., Fernandez, P.G. (1976.): Long term grassland experiments at Cockle Park. Annals Agronomy, 27, 5-6:1027-1042.

3. Ball D.M., Hoveland C.S., Lacefield, G.D. (2002.): Southern forages. Modern Concepts for Forage crop Management. Third edition. PPI and FAR, Georgia, USA, pp. 296.

4. Bašić F., Herceg N. (2010.): Temelji uzgoja bilja, Synopsis, Zagreb.

5. Berendesa, F., Elberse, W.TH. (1990.): Competition, succession and nutrient availability. In: J. Grace and D. Tilman, eds. Perspectives in plant competition. New York : Academic Press, pp 93-116.

6. Butorac A. (1999.): Opća agronomija. Školska knjiga, Zagreb.

7. Carson W.P., Pickett S.T.A. (1990.): Role of resources and disturbance in the organisation of an old field community. Ecology, 71, 226-238.

8. Chambers B. (1994.): Profit from better manure use. In: Living with manures, ADAS Farmer Conference, 21 June 1994, Park House Hotel, Shifnal, ADAS Conference Papers.

9. Crofts A., Jefferson R.G. (1994.) : The Lowland Grassland Managment Handbook. Peterborough: English Nature/The Royal Society for Nature Conservation (The Wildlife Trusts).

10. Dijk T. A., Postmus J., Prins W. H. (1990.): Long-term application of farmyard manure on grassland: effects on herbage yield and distribution of $\mathrm{N}$ and $\mathrm{P}$ in the soil profile. Conference paper : Soil-grasslandanimal relationships. Proceedings of 13th general meeting of the European Grassland Federation, Banská Bystrica, Czechoslovakia, June 25-29, 1990.

11. Dodd M.E., Silvetown J., McConway K., Pottis J., Crawley M. (1994.): Apllication of the British National Vegetation Classification to the communities of the Park Grass Experiment through time. Folia Geobotanica et Phytotaxonomica, Praha., 29, $321-334$.

12. Duffey E., Morris M.G., Sheail J., Ward L.K., Wells D.A., Wells T.C.E. (1974.): Grassland ecology and wildlife management . London: Chapman and Hall.

13. FAO (Food and Agriculture Organization) (2017.): Livestock Solutions for Climate Change. http://www. fao.org/3/a-i8098e.pdf, Accessed date: 9 February 2019.

14. Gašpar I. (1996.): Mineralna gnojiva i gnojidba bilja, INA Petrokemija d.o.o., Kutina.

15. Gill N.T., Vear K.C. (1968.): Agricultural Botany, First Edition - Duckworths. 
16. Jones M.G. (1933.): Grassland management and its influence on the sward. 1 Factors affecting the growth of pasture plants. Empire Journal of Experimental Agriculture 1, 43-57.

17. Julianna, T. , Pál P., Gábor T. (2013.): First results of farmyard manure on hilly grassland. Animal Welfare, Ethology and Housing Systems, 9, 1: 61-75.

18. Kim D.G., Rafique R., Leahy P., Cochrane M., Kiely G. (2014.): Estimating the impact of changing fertilizer application rate, land use, and climate on nitrous oxide emissions in Irish grasslands. Plant Soil 374, 55-71.

19. Kisić I. (2014.): Uvod u ekološku poljoprivredu, Agronomski fakultet Sveučilišta u Zagrebu.

20. Knežević M., Leto J., Perčulija G., Bošnjak K., Vranić M. (2007.): Effects of liquid manure application on yield, quality and botanical composition of grassland. Cereal Research Communications 35 (2): 637-640.

21. Korsmo E. (1938.): Woher kommt das Unkraut? Ernahr. d. Pflanze XXXIV,9,158.

22. Lamkin N. (1990.): Management of manures, slurry and organic residues. In Organic Farming, pp. 86124. Organic Farming Books; Ipswich.

23. Lawes J.B., Gilbert J.H. (1859.): Report of experiments with different manures on permanent meadow land, Parts II and III. Journal of the Royal Agricultural Society of England, First Series 20, 228-272.

24. Malgeryd J. (1994.): Manure characterization. International Agrophysics, 8, 93-101.

25. McCartney D.H., Bittman S., Nuttall W.F. (2004.): The influence of harvest management and fertilizer application on seasonal yield, crude protein concentration and $\mathrm{N}$ offtake of grasses in northeast Saskatchewan. Canadian Journal of Plant Science, 84, 1: 205-212.

26. Mesić H., Bakšić D., Bašić F., Čidić A., Durn G., Husnjak S., Kisić I., Klaić D., Komesarović B., Mesić M., Miko S., Mileusnić M., Nakić Z., Pernar N., Pilaš I., Romić D., Vrbek B., Zgorelec Ž. (2008.): Program trajnog motrenja tala Hrvatske, Projekt, Izrada programa trajnog motrenja tala Hrvatske s pilot projektom, Life Third Countries, LIFE05 TCY/CRO/o00105, Agencija za zaštitu okoliša, Zagreb, str. 131.

27. MPRRR (Ministarstvo poljoprivrede i ruralnog racvoja) (2008.): Pravilnik o dobroj poljoprivrednoj praksi http://www.mps.hr/default.aspx?id=5216, Pristupljeno: 05.07.2020.

28. Müller - Schneider P. (1986.): Verbreitungsbiologie der Blutenpflanzen. Veroffentlichungen des Geobotanischen Institutes der ETH, Stuftung Ruber (Zurich), 85, 1-263.

29. Patel M.R., Sadhu A.C., Patel N.N., Patel R.M., Patel J.C. (2008.): Effect of farm yard manure and nitrogen levels on forage yield and quality of bajra napier hybrid (Pennisetum purpureum). Research on crops, 9, 3: 561-562.

30. Peel W.R. (1938.): Grassland Management for the practical Farmer. London: Macmillian and Co. pp 135140.

31. Powlson D.S., Stockdale E.A., Jarvis S.C., Shepherd M.A. (1994.): A Review of Nitrogen Mineralisation and Imobilisation in the Agricultural Soils, prepared for the Environmental Protection Division of MAFF, London.

32. Rabotnov T.A. (1977.): The influence of fertilisers on the plant communities of mesophytic grasslands. In: W. Krause, ed. Handbook of Vegetation Science No 13: Application of Vegetation Science to Grassland Husbandry. The Hague: Junk.

33. Simao Neto M., Jones R.M. (1987.): Recovery of pasture seed ingested by ruminants. 2. Digestion of seed in sacco and in vitro. Australian Journal of Experimental Agriculture, 27, 247 -251.

34. Simpson N.A., Jefferson R.G. (1996.): Use of faryard manure on semi-natural (meadow) grassland. English Nature Research Reports No. 150 English Nature. 
35. Smith K.A. (1991.): Application of manures and alurries to growing crops. ADAS Eastern Region Soil Science Internal Note, $S S / 91 / 8$.

36. Smith K.A., Unwin R.J. (1983.): Fertiliser value of organic manures in the UK. The Fertiliser Society Proceedings, No.221, London, The Fertiliser Society.

37. Smith K.A. (1980.): Farm waste management: profitable utilisation of livestock manures, Booklet 2081, ADAS/MAFF.

38. Stapledon R.G., Hanley J.A. (1927.): Grassland its management and improvement. Oxford: Clarendon Press.

39. Štybnarova M., Mićova P., Fijala K., Karabcova H., Latal O., Pozdišek J. (2014.): Effect of organic fertilizers on botanical composition of grassland, herbage yield and quality, Agrowyzkum Rapotin Ltd., Vyzkumniku 267, 78813 Vikyrovice, Czesh Republic.

40. Tallowin J.R.B., Kirkham F.W., Wilkins R.J., Smith R.E.N., Thomas G.H., Mountford J.O., Lakhani K.H. (1994.): The effects of inorganic fertilisers in flower-rich hay meadows on the Somerset Levels. An Executive Summary and Summary of Results and Conclusions on the MAFF/DOE/English Nature Tadham Moor Project 1986 - 1993. Peterborough: English Nature Research Reports, No.85.

41. Tallowin J.R.B., Smith R.E.N. (1994.): The effect of inorganic fertilisers on botanical diversity and agricultural production on the Somerset Levels. Eighth and Report to the Management Group of the MAFF/ NCC/DoE Tadham Project . Peterborouogh: English Nature Research Reports, No.87.

42. Thomas B.W., Xiying H. (2017.): Nitrous oxide emitted from soil receiving anaerobically digested solid cattle manure. Journal of Environmental Quality 46, 741-750.

43. Ulen B. (1993.): Losses of nutrients through leaching and surface runoff from manure-containing composts. Biological Agriculture and Horticulture, 10, 29-37.35.

44. Van der Bergh J.P. (1991.): Distribution of pasture plants in relation to chemical properties of the soil. In: Porter, J.K. and Lawlor, D. W. (ed.) Plant Growth - Interactions with Nutrition and Environment. Cambridge: Cambridge University Press.

45. Van Soest P.J., Robertson J.B., Lewis B.A. (1991.): Method for dietary fiber, neutral detergent fiber and nonstarch polysaccharides in relation to animal nutrition. Journal of Dairy Science, 74, 3583-3597.

46. Vranić M., Knežević M., Leto J., Perčulija G., Bošnjak K., Kutnjak H., Maslov L. (2005.): Kvaliteta voluminozne krme na obiteljskim poljoprivrednim gospodarstvima u Republici Hrvatskoj: Monitoring kvalitete travne silaže tijekom dvije sezone hranidbe muznih krava, Mlijekarstvo 55 (4) 283-296, Zagreb.

47. Vranić M., Knežević M., Perčulija G., Leto J., Bošnjak K., Rupić I. (2004.): Kvaliteta voluminozne krme na obiteljskim poljoprivrednim gospodarstvima; Kvaliteta travne silaže na obiteljskim poljoprivrednim gospodarstvima, Mlijekarstvo 54 (3) 165-174, Zagreb.

48. Wang J. (2014.): Decentralized biogas technology of anaerobic digestion and farm ecosystem: opportunities and challenges. Front. Energy Res. 2, 10.

49. Wilson C., Undi M., Tenuta M., Wittenberg K.M., Flaten D., Krause D.O., Entz M.H., Holley R., Ominski K.H. (2009.): Pasture productivity, cattle productivity and metabolic status following fertilization of a grassland with liquid hog manure: A three - year study, University of Manitoba, Winnipeg, Manitoba, Canada R3T 2N2.

50. Zheng Y.H., Li Z.F., Feng S.F., Lucas M., Wu G.L., Li Y. (2010.): Biomass energy utilization in rural areas may contribute to alleviating energy crisis and global warming: a case study in a typical agro-village of Shandong, China. Renew. Sustainable Energy Review, 14, 3132-3139. 


\title{
APPLICATION OF FARMYARD MANURE ON GRASSLAND
}

\begin{abstract}
Grasslands are the basis for livestock production. Grassland fertilization is an agro-technical procedure carried out with the aim of producing high-yield and high quality forage for animal nutrition. Each farm produces manure as a result of keeping animals, and the grassland is an ideal place to apply and thus dispose of the manure produced.

The aim of this paper was to present: (i) basic aspects of lawn fertilizer application with emphasis on farm yard manure (FYM), (ii) recommended quantity, application time and frequency of FYM application on grassland, (iii) impact of FYM application on grassland yield and forage feeding value (v) some of the negative consequences of FYM application on grasslands.

Due to the high variability in chemical composition of FYM and the influence of microclimate, soil and water on the uptake of nutrients by plants, it is necessary to conduct own research in certain microclimatic locations to determine the optimal amount, frequency and time of application on forage yield and nutritive value. FYM has a high potential in grassland fertilization. Its disposal on lawns leads to the recycling of nutrients and the increase of organic matter in the soil, the increase of water and air capacity of the soil and the promotion of the sustainability of agricultural ecosystems. FYM is recommended for application in all systems of agricultural production, especially in organic farming.
\end{abstract}

Key words: grassland, solid manure, fertilization

Primljeno: 22.12.2020.

Prihvaćeno: 17.02.2021. 